\title{
Estimation of growth parameters in a wild population of lion-paw scallop (Nodipecten subnodosus) in Bahia de Los Angeles, Baja California, Mexico
}

\author{
Estimación de parámetros de crecimiento en una población de almeja mano de león (Nodipecten subnodosus)en Bahía de Los \\ Ángeles Baja California, México
}

\author{
Iván Velázquez-Abunader', Jorge Alberto López-Rocha², Marcial Arellano-Martínez³ , Bertha Patricia Ceballos-Vázquez³ \\ and Miguel A. Cabrera ${ }^{1}$
}

${ }^{1}$ Centro de Investigación y Estudios Avanzados del Instituto Politécnico Nacional, Unidad Mérida. Antigua carretera a Progreso km 6. Mérida, Yucatán, 97310. México 2Unidad Multidisciplinaria de Docencia e Investigación, Facultad de Ciencias, Universidad Nacional Autónoma de México, Sisal, Yucatán, 97130, México 3|nstituto Politécnico Nacional, Centro Interdisciplinario de Ciencias Marinas. A.P. 592, La Paz, Baja California Sur. 23000, México e-mail: jvelazquez@cinvestav.mx

Velázquez-Abunader I., J. A. López-Rocha, M. Arellano-Martínez, B. P. Ceballos-Vázquez and M. A. Cabrera. 2016. Estimation of growth parameters in a wild population of lion-paw scallop (Nodipecten subnodosus) in Bahia de Los Angeles, Baja California, Mexico. Hidrobiológica 26 (1): 133-142.

\begin{abstract}
The lion-paw scallop Nodipecten subnodosus is a commercially important resource in the northwest of Mexico; however few studies evaluate its growth. Length of shell was used to estimate individual growth parameters of the lion-paw scallop from a wild population. Monthly samplings were performed from January to December 2006 in Bahia de Los Angeles on the western coast of the Gulf of California, Mexico. Morphometric relationships between total length, height, total weight, and mass weight were estimated. The number of cohorts was determined monthly using the multinomial technique based on a likelihood function. The cohort that was best represented over time was used to fit the stationary growth model of von Bertalanffy. The results indicated that this species presents negative allometric growth and showed high correlation among different morphometric measures $\left(\mathrm{R}^{2}>0.88\right)$. Length frequency distributions showed two cohorts in each sample, except from August to November when there were up to three cohorts, with greater variance in those of intermediate sizes. The growth parameters were: $L_{\infty}=19.06 \mathrm{~cm}, k=0.47$ year $^{1}, t_{0}=-0.19$ years, $C=0.38, t s=0.37$. Due to fluctuations in the growth of the species, assessments should be performed based on age-structured models to support fishery management measures for this species.
\end{abstract}

Key words: Bivalve, likelihood, seasonal von Bertalanffy model, size, wild population.

\section{RESUMEN}

La almeja mano de león Nodipecten subnodosus es un importante recurso comercial en el noroeste de México; sin embargo, son escasos los estudios que evalúan su crecimiento. Se utilizó la longitud de la concha para estimar los parámetros de crecimiento individual de una población silvestre de la almeja mano de león. Se realizaron muestreos mensuales de enero a diciembre de 2006 en Bahía de Los Ángeles en la costa oeste del Golfo de California, México. Se estimaron diferentes relaciones morfométricas entre ellas la longitud total, altura, peso total y peso sin concha. Se determinó el número de cohortes utilizando la técnica estadística multinomial basada en una función de verosimilitud. Se usó la cohorte que estuvo mejor representada en el tiempo para realizar las estimaciones de los parámetros de crecimiento a través del modelo estacionalizado de von Bertalanffy. Los resultados señalan que esta especie presenta un crecimiento de tipo alométrico negativo y mostró una alta relación entre las diferentes medidas morfométricas $\left(R^{2}>0.88\right)$. Las longitudes mostraron dos cohortes en cada muestra, excepto desde agosto hasta noviembre donde se obtuvieron tres cohortes con una elevada varianza en las cohortes de longitudes intermedias. Los parámetros de crecimiento fueron: $L_{\infty}=19.06$ $\mathrm{cm}, k=0.47$ año-1 $t_{0}=-0.19$ años, $C=0.38, t s=0.37$. Debido a las oscilaciones en el crecimiento de la especie, se recomienda realizar evaluaciones basadas en modelos estructurados por edades para sustentar las medidas de manejo pesquero de esta especie.

Palabras clave: Bivalvo, longitud, modelo estacionalizado de von Bertalanffy, población silvestre, verosimilitud. 


\section{INTRODUCTION}

Growth estimations are important for assessing the population's dynamics and for analyzing fisheries through age structured models in order to obtain accurate models, natural and fishing mortality, exploitation rates and catchability. (Velázquez-Abunader et al., 2013). The growth parameters need to be calculated from the data obtained from the same populations as those where the organisms are being caught (Sparre \& Venema, 1997). However, the increase in exploitation of fishery resources and the need to establish management schemes for the different fisheries requires the use of simple and practical methods which in the short-term allow growth parameters to be estimated (Chuenpagdee et al., 2011).

In bivalves age can be determined through of: a) direct counting of growth lines in the shell (Calderón-Aguilera et al., 2010); and b) modal progression analysis (Herrmann et al., 2009). In order to use the first method, it is necessary to validate the periodicity of the growth increments using organisms of a known age, bred in captivity, whereas the second technique provides a quick estimate of the growth parameters but requires progressive monitoring of size structure over time (Sparre \& Venema, 1997). For selected species, age validation has been possible when the organisms have been cultured in several environments, thus providing a basis for the validation of growth parameters. The lion-paw scallop Nodipecten subnodosus (Sowerby, 1835), is a good example, since it has been extensively cultivated across its geographical distribution range.

The lion-paw scallop is a pectinid distributed from 0jo de Liebre lagoon in Baja California Sur, Mexico, including the Gulf of California, to the northeastern coast of Peru (Keen, 1971). In the northeast of Mexico this scallop is considered an important resource due to its attractive flavor, size of the abductor muscle, and the fact that it can reach large sizes in comparison with other bivalves (up to $21.8 \mathrm{~cm}$ in length) (Racotta et al., 2003). According to Chávez-Villalba and Cáceres-Martínez (1992), during the 1970s an important decrease in catch led Mexican authorities to close the fishery for 20 years, reopening once the stock size apparently reached levels suitable for exploitation. Although levels of catch have varied, the volume of production of "scallop" has shown a tendency to increase since 1994 , from $\sim 25 \mathrm{t}$ to a maximum of $321 \mathrm{t}$ in 2008 (DOF, 2012).

Despite the fact that the lion-paw scallop is an economically important resource for fishermen of northwestern Mexico, there are virtually no studies that estimate growth parameters for wild populations of this species. In contrast, several studies have been carried out along this region to evaluate their growth under farming (Barrios-Ruiz et al., 2003; Racotta et al., 2003; Villalejo-Fuerte et al., 2004; Cerón-Ortiz et al., 2006; Taylor et al., 2006; Osuna-García et al., 2008; Arellano-Martínez et al., 2011; Koch et al., 2015). Authors such as Gutiérrez-Villaseñor and Chi-Barragán (1997), Villalejo-Fuerte et al. (2004) and ArellanoMartínez et al. (2011) have found that this species presents accelerated growth during its first year of life (reaching a size of up to $4.5 \mathrm{~cm}$ in length). As expected, growth rates change with study sites, as well as with density, temperature and food availability (Arellano-Martínez et al., 2011). This species shows allometric growth $(\beta<3)$ and spawns at 2 years of age (Villalejo-Fuerte et al., 2004).

The use of length frequencies to estimate growth parameters is appropriate when there is no information available on age using direct methods or when growth patterns in cultured organisms have not pre- viously been studied. Hence the objective of this study was to determine the growth parameters based on size frequency distribution analysis and estimate the length-height and length-total weight ratios of the lion-paw scallop along the western coast of Baja California to provide useful elements for fishery management.

\section{MATERIAL AND METHODS}

Field work. The organisms were collected in a subtropical region of the Gulf of California, Mexico (28 $53^{\circ} 07^{\prime \prime}-29^{\circ} 03^{\prime} 03^{\prime \prime} \mathrm{N}$ and $113^{\circ} 31^{\prime} 46^{\prime \prime}-$ $113^{\circ} 31^{\prime} 18^{\prime \prime}$ W) where there is no established fishery. From January to December 2006, specimens of lion-paw scallop were caught monthly by semi-autonomous Hooka diving at depths of between 5 and $10 \mathrm{~m}$. The total weight ( $T W$ ) and mass weight (MW) were measured for each specimen using one electronic scale (precision $\pm 0.1 \mathrm{~g}$ ), and the length $(L)$ and height $(H)$ of the shell were measured with a Vernier (precision $\pm 0.1 \mathrm{~cm})$.

Morphometric relationships. The morphometric relationships $L-H$ and $T W-M W$ were estimated by linear regression, whereas the $L-T W$ relationship was fitted to the power model, $T W=\alpha L^{\beta}$ using a non-linear least squares, where $\alpha$ is the mean condition of the scallop and $\beta$ is the allometric coefficient (Esmaeili \& Ebrahimi, 2006). The estimated value of $\beta$ was analyzed using a Student's $t$ test in order to determine whether growth is isometric $(\mathrm{Ho}: \beta=3)$ or allometric $(\mathrm{Ha}: \beta \neq 3)$ (Zar, 1999) using the following equation:

$$
\hat{t}=\frac{s . d \cdot_{(L)}}{s . d_{\cdot_{(T W)}}} \cdot \frac{|\beta-3|}{\sqrt{1-R^{2}}} \cdot \sqrt{n-2}
$$

where $\hat{t}$ is the Student's $t$ value, $s . d_{\text {.L) }}$ is the standard deviation of length, $s . d_{.(T W)}$ is the standard deviation of total weight, $\mathrm{R}^{2}$ is the determination coefficient and $n$ is the number of observations (Pauly, 1984).

Modal progression analysis. The distribution of the lion-paw scallop shell lengths $(L)$ was represented graphically by histograms of monthly frequencies; initially the data were grouped into different size-intervals $(1,2$ and $3 \mathrm{~cm} L)$. We present the analysis using a size-interval of $1 \mathrm{~cm}$ $L$, since it allows the modes to be followed over time better. Thus, the observed modal groups were fitted to a multinomial model defined by:

$$
P\left\{x_{i} n, p_{1}, p_{2}, \ldots . ., p_{k}\right\}=n ! \prod_{i=1}^{k} \frac{p_{i}^{x_{i}}}{x_{i} !}
$$

where $x_{i}$ is the number of times that a $i$ event occurs in $n$ samples, $n$ is the sample size and $p_{i}$ are the separate probabilities of each possible event $k$ (Haddon, 2001). In order to estimate the parameters of the model, it was necessary to transform equation (2) into an expression of likelihood, resulting in the following equation:

$$
-\ln L=\left\{x_{i} n, p_{1}, p_{2}, \ldots ., p_{k}\right\}=\sum_{i=1}^{n}\left[x_{i} \ln \left(p_{i}\right)\right]
$$

The main assumption for estimating the parameters of the model is that the size distribution for each mean or modal length is described by a Gaussian distribution, where each mode corresponds to a different size group or cohort of the scallop population (Haddon, 2001). Under 
this condition, estimates of the relative proportions expected for each length interval were described using the following density function:

$$
p_{L}=\frac{1}{\sigma_{n} \sqrt{2 \pi}} \times e^{\frac{-\left(l-\mu_{n}\right)^{2}}{2 \sigma^{2}}}
$$

where $\mu_{n}$ and $\sigma_{n}$ are the mean and standard deviation of the length of each modal group. The expected frequencies were estimated using the logarithmic function of the multinomial distribution (equation 3) and the final values of the model parameters were assigned by comparing the observed and expected frequencies (Haddon, 2001; García-Lizárraga et al., 2011). The objective function for estimating the parameters was defined as:

$-\ln L\left\{L \mid \mu_{i}, \sigma_{i}\right\}=-\sum_{i=1}^{n} L_{i} \ln \left(\hat{p}_{i}\right)=-\sum_{i=1}^{k} L_{i} \ln \left(\frac{\hat{L}_{i}}{\sum \hat{L}_{i}}\right)$

The seed values for estimating the parameters of equation 5 were assigned using criteria from a previous visual inspection of the length frequency distribution (Montgomery et al., 2010). The model parameters were estimated when the negative log - likelihood function was minimized (equation 5), using a non-linear Newton algorithm (Neter et al., 1996).

When the sample had more than one modal group, the Separation Index (SI) was used (Sparre \& Venema, 1997):

$$
S I=\frac{L_{j}-L_{i}}{\left(\frac{S_{j}^{2}+S_{i}^{2}}{2}\right)} \geq 2
$$

where $L_{j}$ and $L_{i}$ are the average lengths of the modal groups $j$ and $i, S^{2}$ and $S_{i}^{2}$ are the standard deviations for the modal groups $j$ and $i$. When $S /$ was $<2$ it was not feasible to separate the normal components from the observed frequencies (Sparre \& Venema, 1997).

Growth function. Once the monthly modes had been obtained, the best represented was followed throughout time, fitting it to the seasonal von Bertalanffy growth equation (Pitcher \& McDonald, 1973) defined by:

$L_{t}=L_{\infty}\left[1-e^{\left[-k\left(t-t_{0}+\left(\frac{k C}{2 \pi}\right) \sin 2 \pi\left(t-t_{S}\right)-\left(\frac{k C}{2 \pi}\right) \sin 2 \pi\left(t_{0}-t_{S}\right)\right]\right.}\right]$
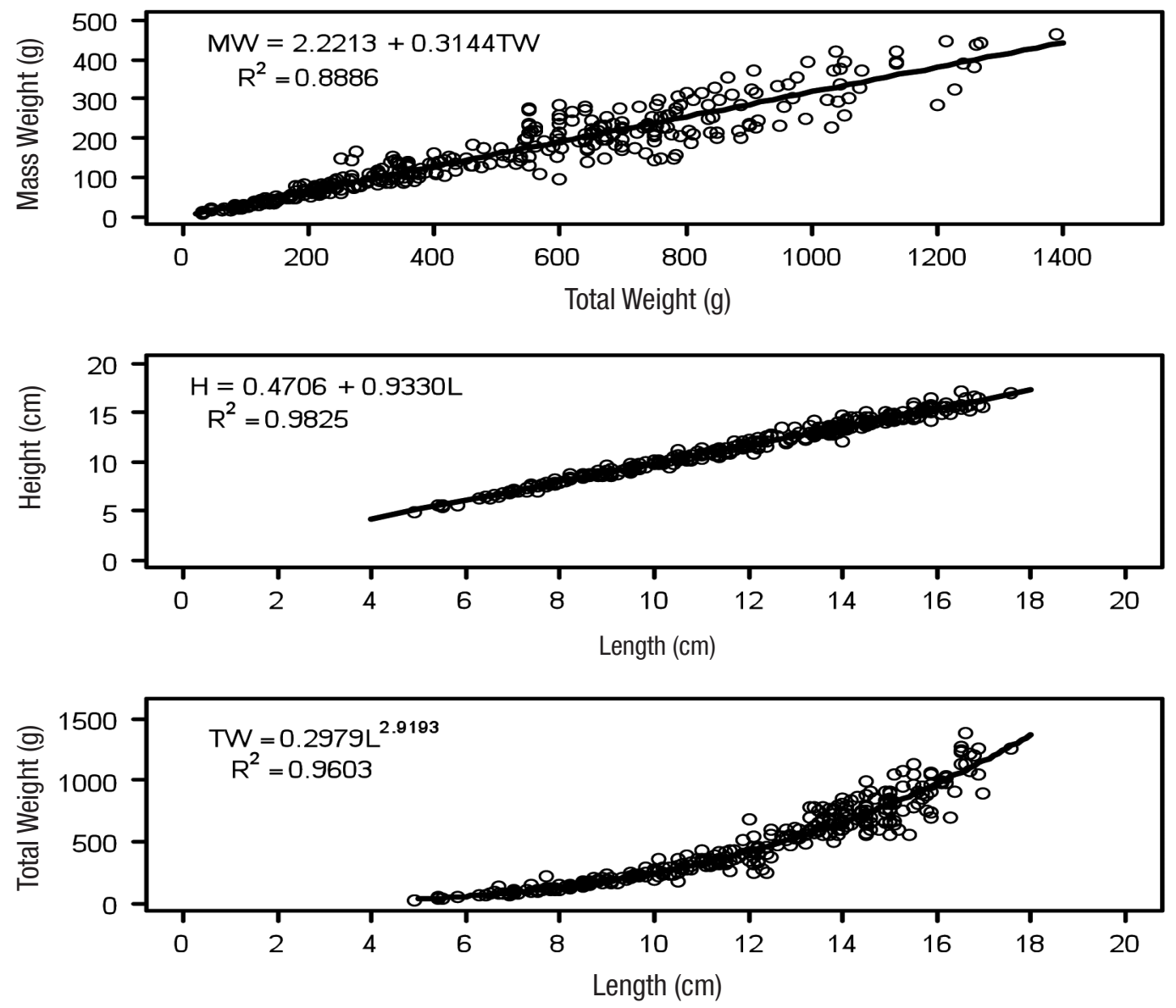

Figures 1a-c. Morphometric relationships of the lion-paw scallop (Nodipecten subnodosus) in Bahía de Los Angeles, Mexico. a) is the total weight - weight without shell relationship, b) is the shell length - height relationship and c) is the shell length - total weight relationship 
where $L_{t}$ is the length at time $t, L_{\infty}$ is the maximum allowable asymptotic length, $k$ is the growth coefficient, $t_{0}$ is the theoretical age when the length is equal to zero, $C$ is the constant that defines the degree of seasonal oscillation (varies between 0 and 1), and $t_{s}$ is the starting point of the oscillation.

Studies carried out for the culture of the lion-paw scallop in the Gulf of California indicated that this species reaches up to $4.5 \mathrm{~cm} L$ in the first year of its life with a growth rate of $0.017 \mathrm{~cm}$ day ${ }^{-1}$ (Ramírez-Arce, 2009). Based on this, the relative age of 12 months was assigned to the first mode $(4.5 \mathrm{~cm} \mathrm{~L})$ located within the lower interval of sizes from the August distribution because individuals shorter than $4.5 \mathrm{~L}$ were not found.

A multiplicative error was assumed in the estimation of $L_{t}$ according to the expression $L_{t}=\hat{L}_{t} e^{s_{i}}$, where $\varepsilon \sim\left(0, \sigma^{2}\right)$ (CerdenaresLadrón de Guevara et al., 2011). In order to estimate the parameters of the model $(\theta)$, the negative log-likelihood value was minimized using the Newton algorithm:

$$
-\ln L(\theta \mid \text { data })=\sum_{t}\left[-\frac{1}{2} \ln (2 \pi)\right]-\left[\frac{1}{2} \ln \left(\sigma^{2}\right)-\left(\frac{\ln L_{t}-\ln \hat{L}_{t}^{2}}{2 \sigma^{2}}\right)\right]
$$

The standard deviation value was obtained by:

$$
\sigma=\sqrt{\frac{1}{n} \sum_{t=1}^{n}\left(\ln L_{t}-\ln \hat{L}_{t}\right)^{2}}
$$

where $n$ is the number of observations (Hilborn \& Walters, 1992).

Confidence intervals. The confidence intervals were estimated at 95\% $(C I)$ for the growth model parameters $t_{0}, C$ and $t_{s}$ (equation 7) using the profile likelihood method (Hilborn \& Mangel, 1997; Cerdenares-Ladrón de Guevara et al., 2011). This is based on a $\chi^{2}$ distribution with $m$ degrees of freedom (Zar, 1999), accepting all the values that satisfy the following condition:

$$
2\left[L(\chi Y \mid \theta)-L\left(Y \mid \theta_{\text {best }}\right)\right]<_{1,1-\alpha}
$$

where $L(Y \mid \theta)$ is the log - likelihood value of the parameters and $L\left(Y \mid \theta_{\text {best }}\right)$ is the likelihood value of the adjusted parameter, $\chi_{1,1-\alpha}^{2}$ is the value of the $\chi^{2}$ distribution at a confidence level of $1-\alpha$ and one degree

\begin{tabular}{|c|c|c|c|c|c|}
\hline Month & $\begin{array}{l}\text { Number of modal } \\
\text { group }\end{array}$ & $\mathrm{n}$ & Mean (cm) & $\begin{array}{l}\text { Confidence Interval } \\
\text { (cm) }\end{array}$ & $\begin{array}{c}\text { Separation Index } \\
\text { (SI) }\end{array}$ \\
\hline \multirow{2}{*}{ January } & 1 & 14 & 9.26 & $8.69-9.84$ & \multirow{2}{*}{3.21} \\
\hline & 2 & 11 & 13.35 & $12.88-13.83$ & \\
\hline \multirow{2}{*}{ February } & 1 & 14 & 8.59 & $8.45-8.73$ & \multirow{2}{*}{4.48} \\
\hline & 2 & 32 & 13.30 & $12.70-13.94$ & \\
\hline \multirow{2}{*}{ March } & 1 & 10 & 7.52 & $7.06-7.98$ & \multirow{2}{*}{5.35} \\
\hline & 2 & 32 & 13.78 & $13.32-14.25$ & \\
\hline \multirow{2}{*}{ April } & 1 & 27 & 9.80 & $9.06-10.54$ & \multirow{2}{*}{3.09} \\
\hline & 2 & 32 & 14.33 & $13.95-14.70$ & \\
\hline \multirow{2}{*}{ May } & 1 & 26 & 12.77 & $11.97-13.57$ & \multirow{2}{*}{2.27} \\
\hline & 2 & 25 & 15.72 & $15.50-15.95$ & \\
\hline \multirow{2}{*}{ June } & 1 & 17 & 9.61 & $8.45-10.78$ & \multirow{2}{*}{2.45} \\
\hline & 2 & 14 & 14.61 & $14.28-14.94$ & \\
\hline \multirow{2}{*}{ July } & 1 & 14 & 11.45 & $10.71-12.19$ & \multirow{2}{*}{2.93} \\
\hline & 2 & 8 & 14.44 & $14.28-14.61$ & \\
\hline \multirow{3}{*}{ August } & 1 & 13 & 4.57 & $4.28-5.69$ & \multirow{3}{*}{$\begin{array}{l}(1,2)=5.16 \\
(2,3)=2.94\end{array}$} \\
\hline & 2 & 17 & 11.09 & $10.23-11.94$ & \\
\hline & 3 & 8 & 15.14 & $14.93-15.35$ & \\
\hline & 1 & 5 & 6.69 & $6.17-6.84$ & $(12)=351$ \\
\hline \multirow[t]{3}{*}{ September } & 2 & 21 & 11.32 & $10.49-12.15$ & \multirow{2}{*}{$\begin{array}{l}(1, \angle)=3.51 \\
(2,3)=3.94\end{array}$} \\
\hline & 3 & 4 & 15.89 & $15.86-15.92$ & \\
\hline & 1 & 13 & 6.70 & $5.70-6.99$ & $(12)=227$ \\
\hline \multirow[t]{3}{*}{ October } & 2 & 7 & 9.43 & $8.79-10.07$ & \multirow[b]{2}{*}{$(2,3)=3.47$} \\
\hline & 3 & 8 & 13.80 & $13.46-14.14$ & \\
\hline & 1 & 9 & 7.86 & $6.12-8.29$ & $(12)=394$ \\
\hline \multirow[t]{2}{*}{ November } & 2 & 11 & 11.65 & $11.33-11.96$ & \multirow{2}{*}{$(2,3)=4.89$} \\
\hline & 3 & 5 & 14.45 & $14.32-14.58$ & \\
\hline \multirow{2}{*}{ December } & 1 & 12 & 7.51 & $6.98-7.65$ & \multirow{2}{*}{3.04} \\
\hline & 2 & 15 & 11.19 & $10.37-12.00$ & \\
\hline
\end{tabular}
of freedom $\left(\chi_{1,1-\alpha}^{2}=3.84\right)$ (Haddon, 2001).

Table 1. Number of cohorts estimated based on length frequency distributions for Bahía de Los Angeles, Gulf of California, Mexico.

$n$ is the number of organism corresponding to each cohort, mean is the average length each cohort. The Separation Index (SI) is shown when more than one cohort was estimated. 

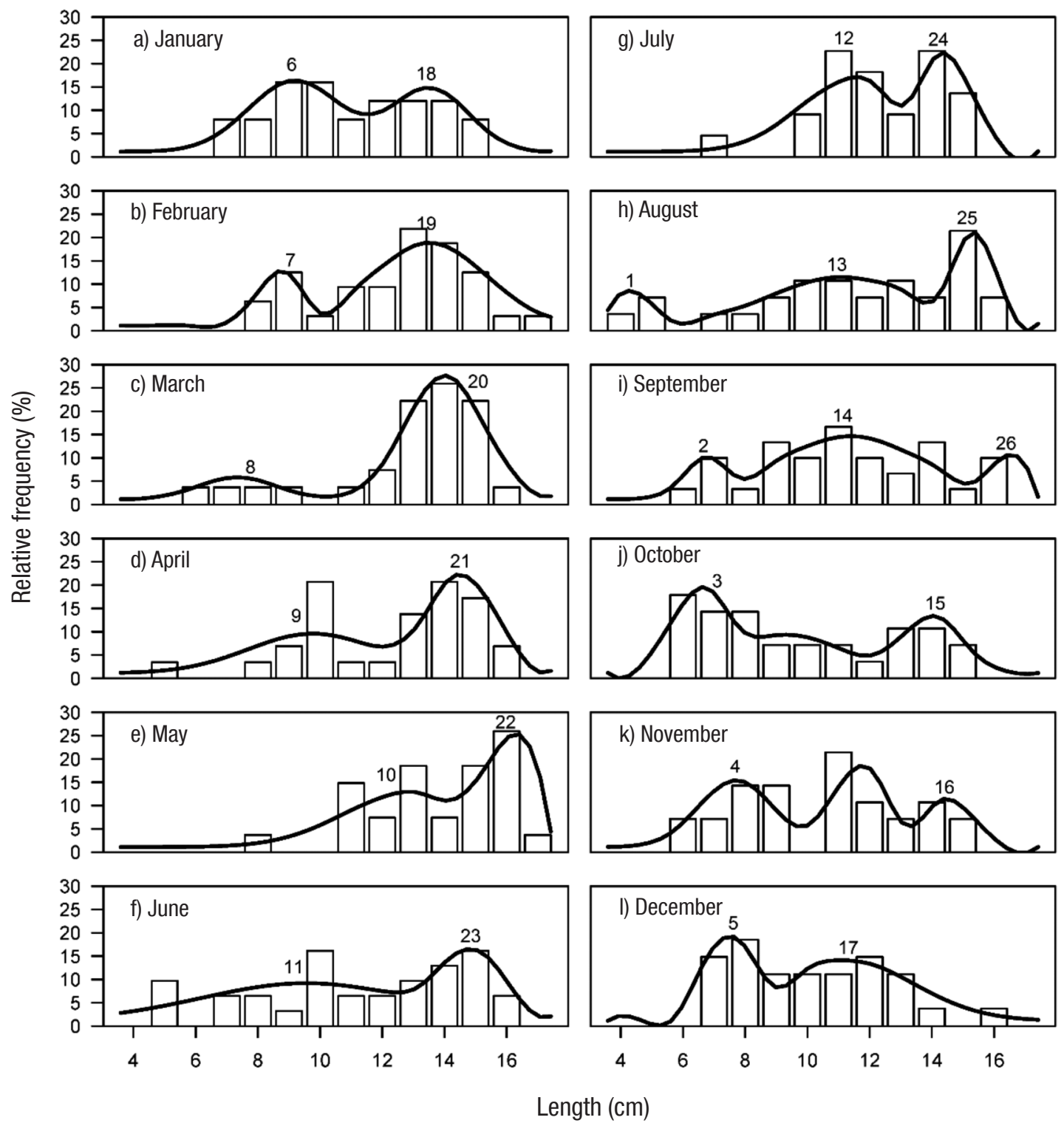

Figures 2a-I. Size frequency distribution (bars) and modal groups (lines) estimated monthly for the lion-paw scallop Nodipecten subnodosus in Bahía de Los Angeles, Mexico. Numbers indicate the modal progression used for growth analysis.

\section{RESULTS}

Often, when more than two parameters are considered in the likelihood profile, the confidence interval tends to be broader (Cerdenares-Ladrón de Guevara et al., 2011) and this occurs when there is a correlation between the model parameters. For the case of the von Bertalanffy model, it is known that the parameters $k$ and $L_{\infty}$ present a high correlation (Welch \& McFarlane, 1990). To solve this problem, the confidence intervals of these parameters were estimated using a contour plot, accepting all the values that satisfy equation (10) but with two degrees of freedom, which corresponded to 5.99 (Zar, 1999).
Population features. A total of 424 organisms were collected during the sampling period. The smallest scallop was caught in August $(4.9 \mathrm{~cm}$ $L)$, whereas the largest was caught in May $(17.6 \mathrm{~cm} L)$. The total weight varied from $29 \mathrm{~g}$ (August) to $1392 \mathrm{~g}$ corresponding to a specimen caught in April.

Morphometric relationships. The $T W-M W$ and $L-H$ relationships were linear, with elevated coefficients of determination $\left(R^{2}=0.89\right.$ and $\mathrm{R}^{2}=0.98$, respectively). The relationship $T W-M W$ presented the greatest variability, however despite this the fit of the linear model was sig- 


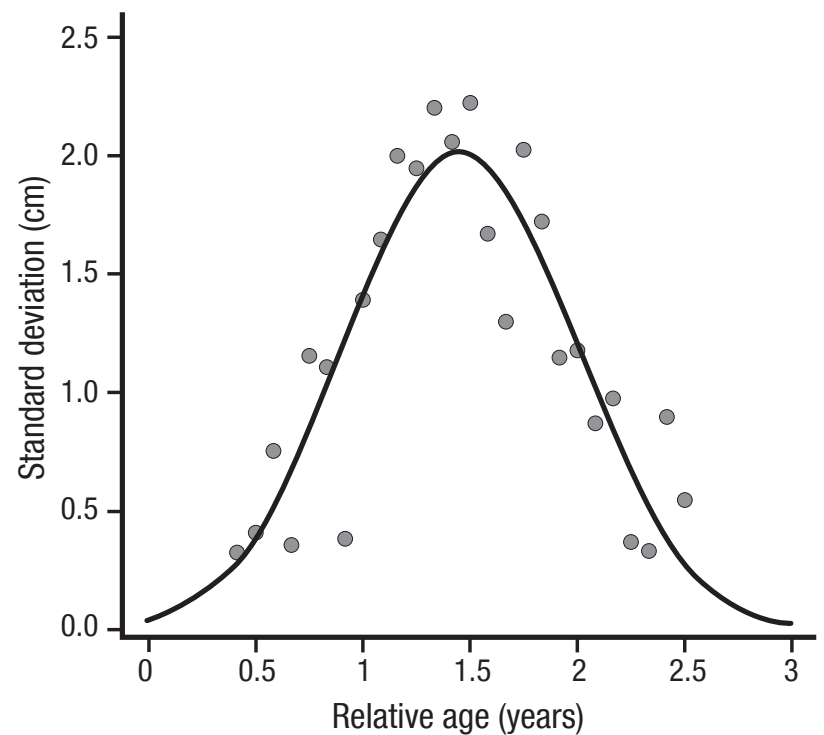

Figure 3. Relationship between the relative age and standard deviation of the modal groups, estimated monthly for the lion-paw scallop Nodipecten subnodosus in Bahía de Los Angeles, Mexico.

nificant $\left(F_{1,332}=2649, p<0.0001\right)$ (Fig. 1a). The value of the slope in the $L-H$ relationship was significantly different from 1 and suggested a greater proportional gain in length than height $(b=0.93, \mathrm{t}=9.79$, $p<0.05$ ) (Fig. 1b). The potential model that explained the $L-T W$ relationship was significant $\left(\mathrm{R}^{2}=0.96, \mathrm{~F}_{1,332}=8034, \quad p<0.0001\right)$. The value estimated for $\beta$ was 2.91 and was significantly different from the theoretical value of $3(\mathrm{t}=2.47, p<0.05)$ (Fig. $1 \mathrm{c}$ ).

Modal progression analysis. The multinomial technique detected distributions with two and three modal groups. The distributions with

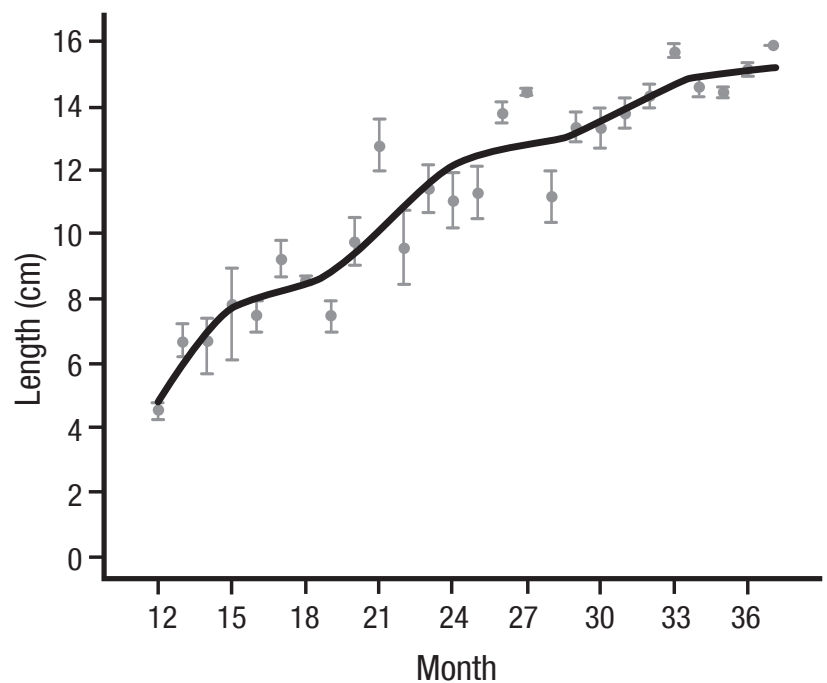

Figure 4. Growth pattern of the lion-paw scallop Nodipecten subnodosus in Bahía de Los Angeles, Mexico. The black line represents the fitted model to the observed data (gray) \pm confidence intervals. three modes were presented from August to November. The mode corresponding to the smallest size was found in August $(4.5 \mathrm{~cm} \mathrm{~L}$; $\mathrm{Cl}=$ $4.28-4.69 \mathrm{~cm} \mathrm{~L}$ ), whereas the largest was detected in September $(15.89 \mathrm{~cm}$ de $L ; \mathrm{Cl}=15.96-15.92 \mathrm{~cm}$ de $L$ ). The mode that could be tracked through time corresponded to the month of August $4.5 \mathrm{~cm}$ $L$ ), providing continuity for three age groups or modal groups to finish the modal progression in September $(15.89 \mathrm{~cm} L$ ) (Table 1 and Fig. 2). The values of the relative ages estimated for the mean lengths of the calculated modes and their respective standard deviations were fitted to a Gaussian curve $\left(R^{2}=0.74\right)$, with the model:

$$
L S D=2.01 e^{\frac{-(1.45 \text {-relative age })^{2}}{-2\left(0.52^{2}\right)}}
$$

where $L S D$ is the standard deviation of the estimated modes (in $\mathrm{cm}$ ); the greatest variability was presented around 1.46 years old (LSD $=0.52$ years) (Fig. 3).

Growth function: Comparing the fitted model with the observed data, the greatest variability occurred between 20 and 25 months, which is possibly due to the high variability in the modal groups estimated in the intermediate sizes as mentioned in Figure 4 . For 12 to 18 as well as for 30 to 37 months of age, the model fitted reasonably well to the observed data. The growth parameters were: $L_{\infty}=19.06 \mathrm{~cm} \mathrm{~L}, k=$ 0.47 years $^{-1}, t_{0}=-0.19$ years, $C=0.38, t s=0.37$ (Fig. 4).

The confidence intervals obtained from the log-likelihood values for $L_{\infty}, k, t_{0}, C$ and $t s$ were: $L_{\infty}=17.8-20.4 \mathrm{~cm} ; k=0.44-0.55$ years $^{-1} ; t$ $=-0.26$ to -0.13 years; $C=0.27-0.51$; and $t s=0.21-0.53$ (Figs. 5 , 6). As expected, the confidence intervals calculated suggest low variability in growth of the youngest individuals and high variability in growth for the oldest.

\section{DISCUSSION}

The results shown here are considered important for estimating the population parameters of the lion-paw scallop using information obtained from a wild population in a subtropical due to its high economic and commercial importance (DOF, 2012). The advantage of estimating growth using wild organisms is that larger and older organisms can be collected. This is not the case in culture where their life cycle is shortened by the harvest periods and high densities in cultures might alter the growth rate. This advantage can be seen when the sample represents a wide range of lengths and is representative of the length structure of the population (Gosling, 2015). In our study this advantage was observed, a wide length interval was obtained however individuals under $4.5 \mathrm{~cm} L$ were not caught. Thus, the growth model is representative from $4.5 \mathrm{~cm} L$.

In the present study, this scallop exhibited disproportionate growth between different parts of its body (greater proportional increase in size than weight, but with a smaller proportional gain in length than height) which suggests a negative allometric growth $(\beta<3)$. The TW $-\mathrm{L}$ relationship showed higher variability in the sizes greater than $13 \mathrm{~cm} \mathrm{~L}$, where the organisms with the same length have different weights. Several authors have indicated that this allometry in growth can be equally influenced by environmental factors including, temperature, (Lodeiros \& Himmelman, 2000; Villalejo-Fuerte et al., 2004; Sumer et al., 2013), quantity and quality of food, density and physiological condition of the 
species (Acosta et al., 2000; Herrmann et al., 2009), high intraspecific competition for space and food (Acosta et al., 2000), as well as the maintenance of physiological favorable surface area-to-volume ratio for pectinid species (Gosling, 2015). Authors as Moragat et al. ( 2001) and Peña (2001) also found a disproportionality in growth of height and width for pectinid species and they suggest this effect can be due to genetic differences among populations because to low flux genetic among them. The irregular shape of the shell for pectinids also facilitate their movement and swim (Gosling, 2015). The relationship between the disproportionality in growth among populations and environmental factors should be analyzed in future studie. The results suggest that the lion-paw scallop from Bahía de Los Angeles consists of two cohorts, except for August to November when there are three, which implies that there is a recruitment period of young organisms in the study area during summer and autumn. On the other hand, the modal groups of intermediate sizes presented the greatest variability, probably due to differences in the growth rate of organisms of the same age. This high variability is characteristic of this species and is particularly noticeable when records are obtained for cultured organisms. Barrios-Ruiz et al.
(2003) found that after the third month of culture there is high variability in sizes for organisms of the same age. This suggests that an overlap of organisms of different ages at intermediate sizes is unlikely, or may be a side effect of the analysis of the information in the present study.

The importance to determining the number of modal groups or cohorts through analysis of length-frequencies, is to understand the population dynamics of the species studied (Velazquez-Abunader et al., 2012). The multinomial method used here, helped to achieve this objective, in addition, this technique allows to detect a modal progression for determining growth rate and recruitment periods through time (Monsreal-Vela et al., 2016). In fisheries, recruitment is usually defined as first age which specimens are caught (Hilborn \& Walters, 1992; Quinn \& Derisso, 1999; Haddon, 2001; Velázquez-Abunader et al., 2012), therefore, the youngest age was assigned to smallest cohort (August) (Fig. 2). In the present study, each cohort was determinate taking into account the following criteria: 1) a visual inspection of the length frequency distribution, 2) growth rate registered in previous studies and 3) knowledge of the biology this species (Velázquez-Abunader et al., 2012).

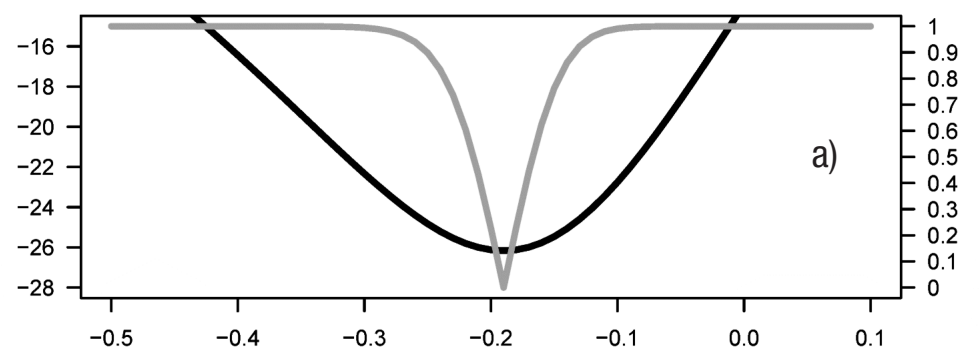

$t_{0}$
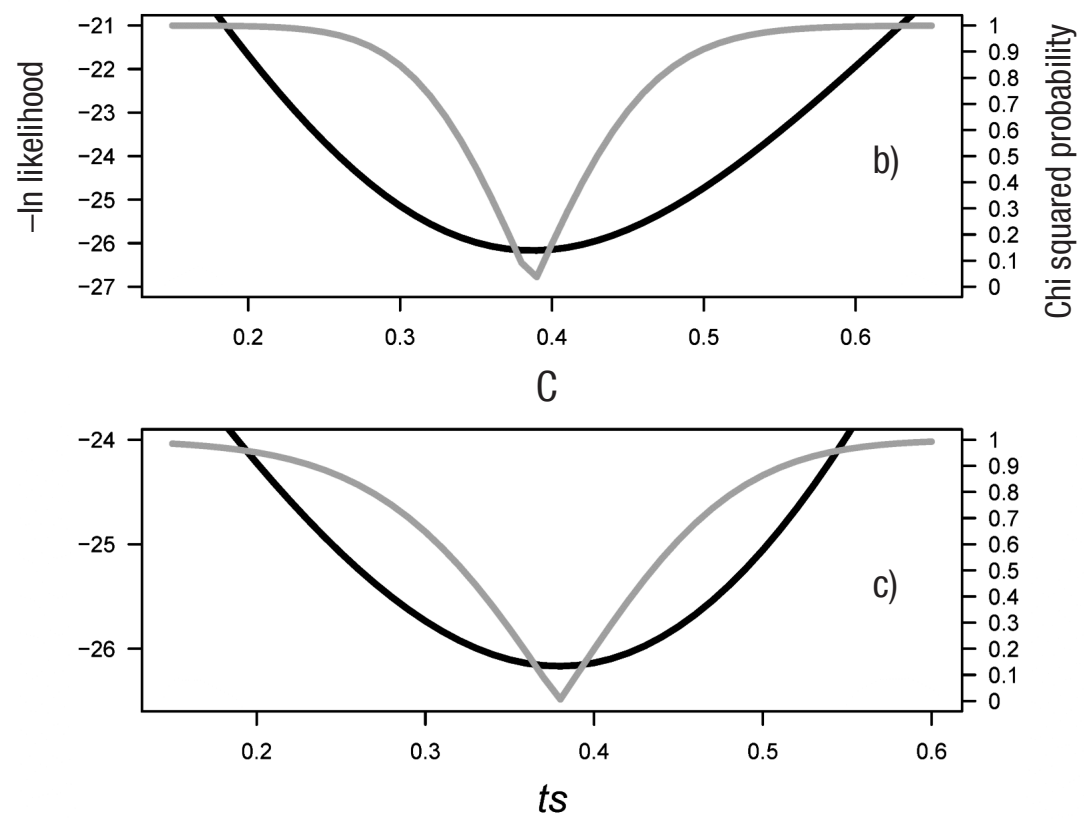

Figures 5a-c. Likelihood profiles to estimate the confidence intervals at $95 \%$ for the parameters $t_{0}(\mathrm{a}), C$ (b) and $t s$ (c) of the seasonalized von Bertalanffy model. Black line represents Chi squared probability. Grey line represents -In likelihood. 


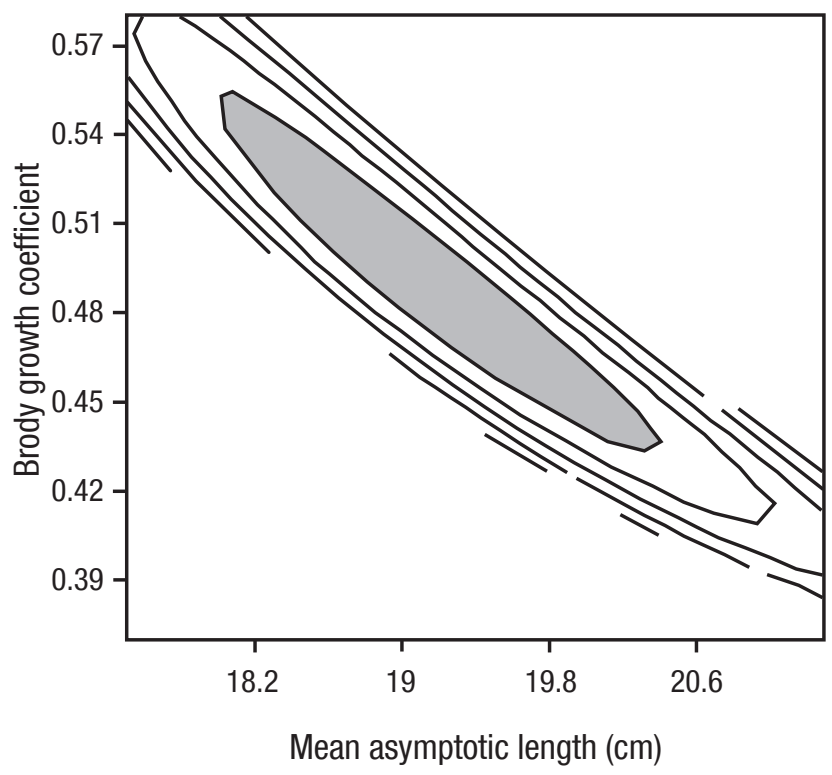

Figure 6. Contour plot for estimating the confidence intervals at $95 \%$ for the parameters $L_{\infty}$ and $k$. The gray area indicates the values that satisfy the condition: $\chi^{2}<5.99$.

The high size variability at intermediate ages coincides with reproductive periods detected for this species in different locations of the peninsula of Baja California (September to November) (ReineckeReyes, 1996; Racotta et al., 2003; Arellano-Martínez et al., 2004; Villalejo-Fuerte et al., 2004). This may be due to a greater investment of energy into reproduction than growth during this period. These possible changes in energy investment for reproductive processes may be responsible for the seasonality found in the growth of this species, where the first oscillation was estimated at 1.5 years old and the second at 2.25 years.

At present, the management measures recommended by the Mexican authorities for the exploitation of the lion-paw scallop are the establishment of a closed season (September to December) and a daily catch limit of 300 to 400 specimens per boat (DOF, 2012). The use of shell length (i.e. minimum size restriction) as a management measure could present problems. This is due to the oscillations in the growth of this species, since individuals of the same size could be different ages.

Since Bahía de Los Angeles is a Natural Protected Area within the Biosphere Reserve category (DOF, 2007), and is considered a Center of Biological Activity (Lluch-Cota \& Arias-Aréchiga, 2000), it is of utmost importance that scientifically validated information to give support to management of fisheries resources in the region. Historically, the target species of the scallop fishery in Bahía de Los Angeles was Argopecten ventricosus, however the catch of this species has decreased drasticaIly (Valdez-Ornelas et al., 2007) to the point that it can be considered a collapsed fishery. Similarly, the lion-paw scallop has been considered overexploited in several zones of the peninsula of Baja California (Taylor et al., 2006). Age-structured models must be considered in future stock assessment for the lion-paw scallop in order to facilitate the management of the fishery.

\section{ACKNOWLEDGEMENTS}

IVA, JALR, MAM and BPCV thank the National System of Researchers (SNI) of the National Council of Science and Technology (CONACyT) for their support.

\section{REFERENCES}

Acosta, V., L. Freites \& C. Lodeiros. 2000. Densidad, crecimiento y supervivencia de juveniles de Lyropecten (Nodipecten) nodosus (Pteroida: Pectinidae) en cultivo suspendido en el Golfo de Cariaco, Venezuela. Revista de Biología Tropical 48: 799-806.

Arellano-Martínez, M., B.P. Ceballos-Vázquez, C. Ruizz-Verdugo, E. Pérez-deLeón, R. Cervantes-Duarte, \& P.M. Dominguez-Valdez. 2011. Growth and reproduction of the lion's paw scallop Nodipecten subnodosus in a suspended culture system at Guerrero Negro lagoon, Baja California Sur, Mexico. Aquaculture Research 42: 571-582.

Arellano-Martínez, M., I.S. Raccotta, B.P. Ceballos-Vázquez \& J.F. ElorduyGARAY. 2004. Energy cycle, reproductive activity, and food availability of the lion's paw scallop Nodipecten subnodosus in the Laguna 0jo de Liebre, B.C.S., Mexico. Journal of Shellfish Research 23: 15-23.

Barrios-Ruiz, D., J. Chávez-Villalba \& C. Cáceres-Martínez. 2003. Growth of Nodipecten subnodosus (Bivalvia: Pectinidae) in La Paz Bay, Mexico. Aquaculture Research 34: 633-639.

Calderón-Aguilera, L.E., E.A. Aragón-Noriega, C.M. Hand \& V.M. Moreno-RIVERA. 2010. Morphometric relationships, age, growth, and mortality of the geoduck clam Panopea generosa, along the Pacific coast of Baja California, México. Journal of Shellfish Research 29: 319-326.

Chávez-Villalba, J. \& C. Cáceres-Martínez. 1992. Scallop culture in the northwest of Mexico. World Aquaculture 23: 20-25.

Chuenpagdee, R., S. Salas, A. Charles \& J.C. Seljo. 2011. Assessing and managing coastal fisheries of Latin America and the Caribbean: underlying patterns and trends. p. 385-401 In Salas, S., R. Chuenpagdee, A. Charles \& Seijo, J.C. (eds.). Coastal fisheries of Latin America and the Caribbean. FAO Fisheries and Aquaculture Technical Paper. No. 544. Rome, FAO.

Cerdenares-Ladrón de Guevara, G., E. Morales-Bojórquez \& R. Rodríguez-SánCHEZ. 2011. Age and growth of the sailfish Istiophorus platypterus (Istiophoridae) in the Gulf of Tehuantepec, Mexico. Marine Biology Research 7: 488-499.

Cerón-Ortiz, A.N., B. Cordero, B.0. Arredondo-Vega \& M. Robles. 2006. Growth of Lyropecten Nodipecten subnodosus Sowerby, 1835 spat fed with three microalgae mixtures diets. Journal of Fisheries International 1: 1-7.

D0F. 2007. Decreto por el que se declara área natural protegida, con la categoría de reserva de la biosfera, la zona marina conocida como Bahía de los Ángeles, canales de Ballenas y de Salsipuedes, comprendiendo la zona federal marítimo terrestre correspondiente a la porción de la costa oriental de la península de Baja California, ubicada frente al Municipio de Ensenada, en el Estado de Baja California. Diario Oficial de la Federación. 5 de junio 2007. 
DOF, 2012. Carta Nacional Pesquera. Diario Oficial de la Federación. México. August 24, 2012.

Esmaeili, H.R. \& M. Ebrahimi. 2006. Length-weight relationships of some freshwater fishes of Iran. Journal of Applied Ichthyology 22: 328-329.

García-Lizárraga, M. A., F. E. Soto-Franco, J. M. J. Ruiz-Velazco, J. I. Velázquez-Abunader, J. S. Ramírez-Pérez \& E. Peña-Messina. 2011. Population structure and reproductive behavior of Sinaloa Cichlid Cichlasoma beani (Jordan, 1889) in a tropical reservoir. Neotropical Ichthyology 9: 593-599.

GosıIng, E. 2015. Marine bivalve molluscs. Wiley Blackwell, West Sussex, UK.

Gutiérrez-Villaseñor, C. E \& G. Chi-Barragán. 1997. Effect of temperature and feeding ratio on the conditioning of Lyropecten subnodosus Sowerby, 1835. p. 73-75. In Felix-Pico, E.F. (ed.). Book of Abstracts 11th International Pectinid Workshop, CICIMAR, La Paz, B.C.S., Mexico.

HadDon, M. 2001. Modelling and quantitative methods in fisheries. CRC Press, Chapman and Hall/CRC Press, Boca Raton, FL.

Herrmann, M., D. Carstensen, S. Fischer, J. Laudien, P. E. Penchaszadeh \& W. E. ARnTz. 2009. Population structure, growth, and reproduction of the wedge clam Donax hanleyanus (Bivalvia: Donacidae) from northern Argentinean beaches. Journal of Shellfish Research 28: 511-526.

Hilborn, R. \& M. Mangel. 1997. The ecological detective. Confronting models with data. Monographs in population biology. Princeton Academic Press, New Jersey.

HILBORN, R. \& C. Walters. 1992. Quantitative fisheries stock assessment: Choice, dynamics and uncertainty. Chapman-Hall, New York.

KeEn, A. M. 1971. Sea Shells of Tropical West America. Stanford University Press, Stanford CA.

Koch V., A. Rengstorf, M. Taylor, J. Mazón-Suástegui, F. Sinsel \& M. Wolff. 2015. Comparative growth and mortality of cultured Lion's Paw scallops (Nodipecten subnodosus) from Gulf of California and Pacific populations and their reciprocal transplants. Aquaculture Research 46: 185-201.

Lluch-Cota, S. \& J. P. Arias-Aréchiga. 2000. Sobre la importancia de considerar la existencia de centros de actividad biológica para la regionalización del océano: el caso del Golfo de California. p. 255263. In: Lluch-Belda, D., J.F. Elorduy-Garay, S.E. Lluch-Cota \& G. Ponce-Díaz (eds.). BAC Centros de Actividad Biológica del Pacífico mexicano. Centro de Investigaciones Biológicas del Noroeste, S.C. México.

LodeiRos, C. J. \& J. H. Himmelman. 2000. Identification of factors affecting growth and survival of the tropical scallop Euvola (Pecten) ziczac in the Golfo de Cariaco, Venezuela. Aquaculture 182: 91-114.

Monsteal-Vela, K., I. Velázquez-Abunader \& G. R. Poot-López. 2016. Model selection for determining the growth of juveniles and sub-adults of two species of shrimp (Decapoda, Penaeidae) in a tropical coastal lagoon. Crustaceana 89: 29-45.

Montgomery, S. S., C. T. Walsh, M. Haddon, C. L. Kesby \& D. D. Johnson. 2010. Using length data in the Schnute model to describe growth in a metapenaeid waters off Australian. Marine and Freshwater Research 61: 1435-1445.

Moragat, D., Avendaño, M., Peña, J., Le Pennect, M., Tanguyt, A., \& Baron, J. 2001. Genetic and morphological differentiation between two pectinid populations of Argopecten purpuratus from the northern Chilean coast. Estudios Oceanológicos 20: 51-60.

Neter, J., M. H. Kutner, W. Wasserman \& J. Nachtschien. 1996. Applied linear statistical models. McGraw-Hill/Irwin, Chicago, IL.

Osuna-García M., A. Hernández-Llamas \& J. M. Mazón-Suastegul. 2008. Production dynamics of the giant lions-paw scallop Nodipecten subnodosus cultivated off-bottom. Aquaculture 274: 260-267.

Pauly, D. 1984. Fish population dynamics in tropical waters: a manual for use with programmable calculators. ICLARM Stud. Rev. 8, 325 p.

PEÑA, J. B. 2001. Taxonomía, morfología, distribución y hábitat de los pectínidos Iberoamericanos. In Maeda-Martínez, A. N. (ed.). Los moluscos pectínidos de Iberoamérica: Ciencia y Acuacultura. Cap. 1: 1-25.

Pitcher, T. J. \& P. D. M. McDonald. 1973. Two models for seasonal growth in fishes. Journal of Applied Ecology 10: 599-606.

Quinn, T. J. \& R. B. Deriso. 1999. Quantitative fish dynamics. Oxford University Press, New York.

Racotta, I. S., J. L. Ramírez, A. M. Ibarra, M. C. Rodríguez-Jaramillo, D. CarreÑo \& E. PALACIOS. 2003. Growth and gametogenesis in the lion-paw scallop Nodipecten (Lyropecten) subnodosus. Aquaculture 217: 335-349.

Ramírez-ArCE, J. L. 2009. Evaluación de la ventaja productiva y grado de esterilidad en triploides de almeja mano de león Nodipecten subnodosus (Sowerby 1835) como una alternativa para el cultivo en el Parque Nacional Bahía de Loreto, Golfo de California. MSc thesis, Centro Interdisciplinario de Ciencias Marinas, Instituto Politécnico Nacional, La Paz, BCS, México.

ReineCKe-Reyes, M. A. 1996. Madurez y desove de la almeja mano de león Lyropecten subnodosus Sowerby, 1835 (Bivalvia: Pectinidae) en la Laguna 0jo de Liebre, B.C.S., México. Boletín Pesquero CRIP La Paz 3: 17-20.

Sparre, P. \& S. C. Venema. 1997. Introduction to tropical fish stock assessment. Part I. Manual. FAO Fisheries Technical Papers 360(1). Rome, FAO.

Sumer, C., I. Teksam, H. Karatas, T. Beyhan \& C. M. Aydin. 2013. Growth and Reproduction Biology of the Blue Crab, Callinectes sapidus Rathbun, 1896, in the Beymelek Lagoon (Southwestern Coast of Turkey). Turkish Journal of Fisheries and Aquatic Sciences 13: 675-684. 
TayLOR, M., V. KoCh, M. WolfF, \& F. Sínsel. 2006. Evaluation of different shallow water culture methods for the scallop Nodipecten subnodosus using biologic and economic modeling. Aquaculture 254: 301-316.

Valdez-Ornelas V., 0. Aburto-Oropeza, E. Torreblanca-Ramírez, G. Danemann \& R. VIDAL-TALAMANTES. 2007. Recursos pesqueros. In Danemann, $G$. \& E. Ezcurra. (eds.). Bahía de Los Ángeles: recursos naturales y comunidad Línea base 2007. Pronatura Noroeste AC. Secretaría de Medio Ambiente y Recursos Naturales. Instituto Nacional de Ecología. San Diego Natural History Museum. México. p. 429-456.

Velázquez-Abunader, J. I., A. Hernandez-Herrera, S. Martinez-Aguilar, J. G. Díaz-Uribe \& E. Morales-Bojórouez. 2012. Interannual variability in mantle length structure, recruitment, and sex ratio of jumbo squid, Dosidicus gigas, in the Central Gulf of California, México. Journal of Shellfish Research 31: 125-134.

Velázquez-Abunader, I., S. Salas \& M. A. Cabrera. 2013. Differential catchability by zone, fleet, and size: the case of the red octopus (Octopus maya) and common octopus (Octopus vulgaris) fishery in Yucatan, Mexico. Journal of Shellfish Research 32: 845-854.

Villalejo-Fuerte, M., M. Arellano-Martínez, M. Robles-Mungaray \& B. P. CeBALLOS-VÁZQUEZ. 2004. Notes on the growth, survival, and reproduction of the lion's paw scallop Nodipecten subnodosus maintained in a suspended culture. Hidrobiológica 14: 161-165.

Welch, D. W. \& G. A. McFarlane. 1990. Quantifying growth of female Pacific hake (Merluccius productus): an example of measuring uncertainty and bias in non-linear parameter estimation. Canadian Journal of Fisheries and Aquatic Sciences 47: 672-681.

ZaR, J. H. 1999. Biostatistical analysis. 4a ed. Prentice- Hall, Nueva Jersey.

Recibido: 25 de junio de 2014.

Aceptado: 24 de febrero de 2016. 